\title{
'We're the lassies from Lancashire': Manchester Corinthians Ladies FC and the use of overseas tours to defy the FA ban on women's football Jean Williams
}

\begin{abstract}
The FA banned women's football from the grounds of Association-affiliated clubs in 1921, on the grounds that the organization perceived that football was 'unsuitable' for women and too much money raised for charity had been absorbed in player expenses. But women continued to play. This article analyses how Manchester Corinthians Ladies Football Club, which had been formed in 1949, was able to sustain a varied range of overseas tours and domestic matches in spite of the ban. Using a range of methods, including oral history, family history interviews, a reunion of the surviving players and player memorabilia, firstly, the article provides a history of Corinthians and Nomads from 1949 onwards. Secondly, the article uses oral history to reflect what the players felt about playing for the club and particularly its overseas tours, and charity work. Not all of the players are represented due to constraints of space, but this is an introduction to a larger ongoing project to reclaim the teams' history. Finally, the article argues that it is important to examine the 1950s and 1960s, decades when women's football was an unregulated activity, in order to understand that which followed once the FA ban was lifted in 1969.
\end{abstract}

The Corinthians Song

We're the lassies from Lancashire

Oh, What a team!

Fa la la la la la

We'll beat anyone who we play

Makes no difference, home or away

We have the talent

Our youngsters are gallant

The lassies from Lancashire

Ole!

The Nomads Song

(to the tune of Me and My Gal, 1942)

The Northern Nomads are coming today

The Northern Nomads are on their way

The Corinthians they are playing

And everybody's been saying

That the crowd will be swaying

With excitement and glee

With excitement and glee.

The Northern Nomads are a very good team

They are the finest team the world's ever seen

And if they score a little goal

Just one, or two, or three, or four, or more

We'll call them the team of the year! 


\section{Introduction}

It is well known that the FA banned women's football from the grounds of Association-affiliated clubs in 1921, on the grounds that the organization perceived that football was 'unsuitable' for women and too much money raised for charity had been absorbed in player expenses. ${ }^{1}$ This article concerns the continued use charity matches, both domestically and overseas tours, to defy the ban by the Manchester Corinthians Ladies Football Club, which had been formed in 1949. The short song above is one that the players would sing on tour, along with others celebrating their victories.

Corinthians was to be one of the most important women's clubs after 1945 to pioneer women's football as socially acceptable, benevolent and by the late 1950s, internationally as a celebration of Mancunian civic pride. Percy Ashley formed Corinthian Ladies in 1949, mainly so that his daughter, Doris, could play in a team. Percy was a scout for Bolton Wanderers and a well-known local referee. His daughter Doris was a magnificent player, but there was no existing local team, in Manchester. Doris had a cleft palate and was profoundly deaf. ${ }^{2}$ So it would seem that building a team around her, and all players remembered her as an outstanding footballer, was a way of supporting her sporting interest, and also helping her to socialize.

But Manchester Corinthians were not like the upper class amateurs from whom they took their name. Their home ground on Fog Lane Park, Didsbury and facilities were sparse, and players had to be both very determined to play football and resilient: several reminisced washing post-match in duck ponds as there was no running water in the changing rooms, which were also unheated. There were very few other women's teams in the region and teams that had been once great, such as Dick, Kerr's Ladies of Preston, were in decline. Therefore in 1957, a second team linked to Manchester Corinthians was formed by Percy Ashley under the name 'The Nomads', or less frequently 'All Stars', to enable them to play against each other in international charity matches. This was necessary because, so far, there is no evidence of the level of women's football league activity in the 1950s and 1960s that Williams found in the 1920s in the North of England. ${ }^{3}$ The Corinthians were entirely self-funded and played in a way that combined some limited domestic competition with overseas tours.

It has often been said that 'Where Manchester leads others will follow,' however this has seldom been applied to the relatively neglected topic of women's football in the city, and its surrounding area. Manchester Corinthians were able to use the latest travel technology to defy the FA ban and take part in tours to the European Cup in Berlin in 1957 winning against Germany 4-0 and reportedly singing Land of Hope and Glory on their victory lap, before going on tour to Portugal for a month the same year. More overseas trips followed, including six weeks to Portugal/ Madeira, and in 1959 two weeks to The Netherlands. The most ambitious schedule was twelve weeks in South America \& the Caribbean in 1960, followed by one month to Italy in 1961, playing on the grounds of Juventus, Milan and other major clubs. During their existence, both teams toured extensively; including to Ireland in 1962, Morocco in 1966, and France in 1970, in all winning more than fifty trophies.

Presenting the teams as pioneering, a relatively relaxed form of feminist protest at the FA ban, and both altruistic and humanitarian gave the club a niche in the 
market for football that Percy Ashley astutely amplified. In an increasingly meritocratic society, the Corinthians earned their right to play football by doing good, in a fairly modest way. Even for an organization so supercilious as the FA in the 1950s and 1960s, it would have seemed crass to try and curb the activities of the Corinthians, and so they flourished. This gave the players, and Ashley, life experiences way beyond most of the people they worked with during the week. So successful was this strategy that, by the time the FA lifted the ban on women's football in England in 1969, Corinthians and Nomads had between them raised over $£ 275,000$ for charity; mostly for the International Red Cross and Oxfam.

So this article has three main research aims. Firstly, it looks at the development of Corinthians and Nomads from 1949 onwards to provide the basic chronology of the clubs as two of the most significant women's teams before the formation of the Women's Football Association (WFA) in 1969 with 44 clubs. ${ }^{4}$ This has not been the subject of a full length academic article before and the longer project is to write a book on the club. The sources for the club history in this article draw on the scrapbooks of long time goalkeeper, Carol Aiken, and oral testimony of the players, many of whom survive and were reunited at the National Football Museum on 30 September 2018, the eldest of whom was eighty four years of age, who had begun playing when fourteen in 1949. Secondly, the article uses oral history to reflect what the players felt about playing for the club and particularly its overseas tours, and charity work. I am particularly grateful for an interview with Carol Aiken, whose mother Gladys and father George also managed the club after Percy Ashley died and an interim manager, William Oldfield, resigned. I am also especially indebted to Anne Grimes who played as goalkeeper between 1957-1961; and to star players Margaret Whitworth and Margaret Shepherd.

Thirdly then, the article argues that while the extant literature on women's football has emphasized women's charitable matches as part of the legacy of World War One, the historiography has seldom considered how this developed after World War Two. ${ }^{5}$ This is particularly important, the article contends, for the forms of women's football that followed once the FA ban was lifted. That is, as a primarily amateur sport, initially unfunded by the FA and reliant on central government grants. Gladys Aiken, for instance was the membership secretary of the WFA from 1972-74. This gives an insight into women managing their own teams, well before it was conventional for women to work in the wider football industry. Interestingly, the Corinthians' trainer on many overseas tours, Pat Dunn was the first woman to qualify as a referee in 1967 and was a vocal critic of the FA's attitude to women. Dunn was briefly the first Chair of the WFA in 1969 before the FA requested that she be replaced by a man less than a year into her tenure, and male referee Pat Gwynne took over. Defiant, Dunn went on to referee an international match in 1969. Pat Dunn would later travel to the unofficial World Cup in Mexico with Harry Batt's team in 1971 as their trainer. So the links between unofficial women's football teams and an emergent WFA, affiliated to the FA on the same basis as a County Association, are also pertinent to the Corinthians as a case study club.

\section{Manchester Corinthians: a History}

The name was chosen to reflect the amateur Corinthian values that had preceded professionalism, and fair play. As amateurs the team was perhaps appealing for generosity in social attitudes, and also emphasising it was a 'ladies' football club in 
the terminology used at the time. Accordingly, the 1949 Manchester Corinthians team was made up of career women, from typists to machinists, who trained and played at Fog Lane Park in Didsbury every Sunday, whatever the weather. There are snapshots of them trailing buckets of water to the changing rooms nearby as there was no running hot water. Percy Ashley was assisted by Derek Ingham as trainer, and, if any players were injured Ingham would use his motor-bike as a means of conveying them to Mr Beardo, the osteopath. Players reported being more fearful of the well-intentioned cure, than the initial injury. It is clear that Percy Ashley wanted to contest the FA ban as well as to provide top level coaching for his team, and individual players reported specific coaching sessions on using defenders as attacking wingbacks, and Percy's blackboard sessions on team tactics. A serious disciplinarian, no boyfriends or relatives were allowed on the team coach, and Percy emphasised the sporting aspects of Corinthians, at the cost of social niceties if required.

Between 1949 and 1956, most of the Corinthian's matches were domestic, and this is perhaps unsurprising. By 1951 they were acclaiming themselves the 'Premier' team in Britain, having won (in the order listed in the programme) the Southern Cup; Manchester Area Cup; Sports Magazine Cup; Roses Trophy; Midland Trophy; Cresswell Trophy; Odeaon Championship Trophy; Belle Vue Trophy, and the Festival of Britain Championship Trophy. ${ }^{6}$ Having travelled a reported 9,000 miles so far, Corinthians had reportedly raised $£ 8,000$ for aid organizations varying from local causes such as the Multiple Sclerosis Society Salford and District Branch, to national and international health charities, including the British Limbless ExServicemen's Association, and the British Empire Leprosy Relief Association. While Reports of twenty-six teams entering tournaments suggest a healthy level of competition, the scale of Corinthians' ambitions was about to change.

In 1957 Corinthians were invited to tour Portugal on behalf of the International Red Cross. Next they were invited by the International Ladies Football Association, a German based organisation, to represent England in a European championship against Austria, Luxembourg, The Netherlands and West Germany. In the final, held in Berlin, Corinthians beat Germany 4-0 in front of a crowd of 40,000. Bert Trautmann, who was the Manchester City goalkeeper, and had presented the team with the Festival of Britain Trophy in 1951, travelled in 1957 as their interpreter. The crowds were considerable, and in Stuttgart they played before 45,000 people. Quite how Trautmann was funded to interpret, and why he specifically joined a women's football team from his adopted city to West Germany remains unclear as no paperwork has emerged from these early tours. But the trip took place within a year of his role in Manchester City winning the FA Cup Final 3-1 in 1956, playing the last quarter of an hour with a seriously injury and his fame was perhaps at its height, during his year of convalescence in the 1957/8 season. The Corinthians players have many snapshots of Trautmann and remembered him as very kind and supportive of them as a team, enjoying socializing with a star male player as part of their recently won European fame.

This European victory, combined with a greater sense of spectacle, and international travel, seemed to change Percy Ashley's ambitions and business model. Overseas tours became annual events for a period of time before his ill 
health prevented them. In 1958 the International Red Cross invited Corinthians and Nomads to play against each other in Portugal and Madeira, drawing huge crowds in major stadia of important mane's professional clubs, like Benfica in Lisbon. In 1959 the team went to The Netherlands, playing teams from Haarlem and Utrecht. The Red Cross then invited both teams to tour South America and the Caribbean, which again attracted huge crowds in 1960 and the trip lasted three months. While some of the young women could afford to go because they were still at school, others like Sylvia Gore gave up their office jobs to take the opportunity to play abroad in major stadia to large crowds. ${ }^{7}$

The displeasure of the FA ran to sexist sourness, but could not extend to outright prohibition, since women's football was unregulated. The Daily Express featured a team photo in smart travelling suits undercut by a quotation from an amused Nat Lofthouse, 'Let the girls go abroad'. Meanwhile, the England coach Walter Winterbottom was quoted as saying:

Well, one cannot quite take it seriously can one? The experts say that

Football is not suitable game for women anyway. And they certainly can't look attractive playing it. Still, I'm quite sure that their tour to South America will cause quite a stir, even if the spectators aren't exactly concentrating on the finer points of the game. ${ }^{8}$

The seriousness of both the Red Cross and the Corinthians can be evidenced by the schedule, which involved 29 flights and comprised:

Table 1 Corinthians and Nomad Tour to South America May-August 1960

\begin{tabular}{lll}
\hline $\begin{array}{l}\text { Destination } \\
\text { Manchester }\end{array}$ & Length of Time There & Hotel Name \\
Brussels & 10 hours (connecting flight) & \\
New York & 1 nights & Hotel Sheraton \\
New York & 3 nights & Hotel Sheraton \\
Caracas & 10 days & Humboldt \\
Maraciabo & 3 nights & Granada \\
Valera & 1 night & Guadalupa \\
Barquismento & 1 night & La Francia \\
Porto Cabello & 3 nights & Balnerrio \\
Valencia & 2 nights & La Paris \\
Caracas & 11 days & Pinar/ Humboldt \\
Aruba & 2 nights & Strand \\
Curaçao & 2 nights & Park \\
Baranquilla & 1 night & Victoria \\
Santa Marta & 2 nights & Park \\
Baranquilla & 2 nights & Victoria \\
Bogota & 6 nights & San Francisco \\
Manizales & 2 nights & Escorial \\
Medellin & 2 nights & Veracruz \\
Bucaramanga & 2 nights & Bucarica \\
Cari & 4 nights & Aristi \\
Aruba & 4 nights & Strand \\
British Guyana & 3 nights & Woodbine \\
Suriname & 5 nights & Rosedale Guest House \\
Port of Spain (Trinidad) & 1 night & Bretton Hall \\
& &
\end{tabular}


Kingston (Jamaica)

New York

London

Manchester
12 nights

connecting flight

connecting flight
Flamingo

Some readers may think the listing of the New York nights early on in the trip is an error, but en route to Caracas first time around, an engine on the plane failed two hours into the flight, and the team had to return to New York to stay an additional three nights before completing the flight to Venezuela. Perhaps unsurprisingly, the 1961 tour was an easier event to arrange in Italy, then becoming an important locus for women's football and in 1962 an even more manageable trip to Ireland and in 1963 a modest tour of the Isle of Man. While domestic football continued, it was the international reputation of being invited by global charities that gave Corinthians an added gloss that most domestic teams did not have.

Not all the tours were equally successful and there was evidence of experiments going awry. The tour to the Tunisia Mediterranean games was really a flop from a football perspective with poor crowds, and cultural values unused to the idea of women's football. It turned more into a holiday than a sports tour, with players quite content to be in the sun for three weeks. In 1966 the major overseas tour was three weeks in Morocco. First the team flew to Gibraltar, sailing from Gibraltar to Tangiers and then travelling 3,000 miles by coach through Casablanca, Fes, Marrakech, Oujah and Rabat. Kath Davis (née Moxon) remembered: 'We played in a flood lit stadium in Casablanca with a crowd of 22,000!'9 A Programme for a match at Brighouse in 1967 reported that the Morocco tour had raised $£ 8,500$ for the Red Cross, and that at the Oujah match, 3,000 spectators had been unable to get into the stadium due to the popularity of the fixture. ${ }^{10}$ It is difficult to know whether these comments were hyperbole to entertain the spectators or whether the novelty of women's football in Morocco at the time drew large crowds. It may well have been a bit of both. Like Dick, Kerr's before them, the Manchester Corinthians were not afraid to claim their place in history: claiming to be 'Unbeaten by any foreign team at home or abroad and had one run of 141 matches unbeaten' in the full knowledge that most of their opposition was effectively their own second team. A 1965 programme recorded the record: Corinthians played 394, won 353, lost 20, drawn 21, goals for 2,122, goals against 473 and Nomads played 68, won 47, lost 11, drawn 10, goals for 368 , and goals against $121 .^{11}$

Percy Ashley died in October 1967, and his legacy proved difficult to maintain. What is useful, in addition, from the Brighouse programme are comments on the business model that Percy Ashley had developed to that point in order to raise large sums. Firstly, the main problem women's football had, in appearing to be unspectacular, was that many matches had to be staged on open parkland, as Association-affiliated grounds were not available due to the ban. However, the game at Brighouse was played for a local charity, thus combining entertainment spectacle with altruism. Programme notes emphasised that the women gave their time and performance for free, benefitting only from 'a coach ride and a little supper' in reward. Finally, Percy Ashley's preferred style of play, and one for which he would swap players between Corinthians and Nomads/ All Stars, was attacking 
football with a high score: 'Mr Ashley says a score of $10-1$ is better than $2-1$ from a playing point of view, and also for spectators.' ${ }^{2}$ So even if it was a bit chillier in Brighouse in May 1967, than it had been in Morocco in 1966 the spectators could cheerfully expect their 2 shilling admission at the gate 11 shilling and sixpence with programme advance purchase, under 15s 1 shilling) to buy them a lively game between two well matched sides, and to make a charitable donation to their local good causes, along with a benevolent form of feminist alliance.

Behind a relatively relaxed form of sporting philanthropy, however, lay an enormous logistical task. Gladys Aiken took charge of the team in 1968, and kept a series of scrapbooks to trace the journey of the Corinthians. They give a personal account of the activity of the team, featuring newspaper cuttings glued alongside match day programmes, as well as photographs of the team both during play and enjoying themselves post-match. There was a lot of post match time in which to enjoy themselves. And they did. The major achievement of 1968 was to win the inaugural Deal Ladies tournament against 50 other teams, 9-0 and with Nomads also reaching the quarter finals. Corinthians won all 15 domestic matches in 1968, scoring 170 goals for, and conceding just 5.

In 1970 Manchester Corinthians flew to Rheims, France to play in a two day knock out competition against women's teams from the Italian club Juventus, the Czech club Kaplice, and the home club Stade de Rheims. The print media casually referred to the teams as England, France, Italy and Czechoslovakia but there seemed no direct attempt on behalf of the organisers to identify teams as representative sides. This would prove to be significant. Arrangements were left to manager Gladys Aikin and coaching organized by trainer John Rule. In an interesting letter from the manager of Stade de Rheims FC (French spelling) Pierre Geoffroy, on 20 April 1970, he suggests that this will be an annual tournament. ${ }^{13}$ Expected in 1970 were AFC Roma, champions of Italy, Slavia Pramen Kaplice winner of a Czech national tournament 1969, and Stade de Rheims FC. Then in a letter dated 11 May 1970 the lineup was changed to Corinthians, Nomad, Juventus Turin, Kaplice and Rheims. ${ }^{14}$ It is worth briefly covering the tournament before discussing why an invitation form Geoffroy was particularly significant in 1970.

Another letter, dated 22 May 1970, from Pierre Geoffroy suggested Corinthians fly Air France and get return tickets for sixteen people, and Rheims would fund airfare, accommodation and rail transport. Interestingly the contract itself has the letterhead The Corinthians and Nomad Globe Trotters Ladies Football Club of Manchester. The scrapbook contains telegrams from well-wishers Pat and Alf Dunn of Weymouth, and others. Corinthians flew from Ringway to Orly on 25 June, flight BEA 77-10-76. Games took place at Châlon sur Marne and at Épernay, with the price of entry 6 Francs and no concessions. Juventus beat Rheims to get to the final against Corinthians. For Juventus the players were: 1. Amari 2. Rossero 3. Grisorio 4. Fillipeto 5. Coda 6. Losito 7. Cum 8. Gianotti 9. Abate 10. Bertolo 11. Germena and the reserves were 12. Branca 13. Cum 14. Petronillo. Perhaps there were two sisters or relatives in the side? For Stade de Rheims the squad was not numbered but the programme included the following names which I have copied as they were recorded and may or may not be accurately spelled: Marie-Louise Butzig, Régine Pourveux, Ghislaine Royer, Chantal Lebrun, Nicole Mangas, Marie-Claire 
Harant, Michèle Darbre, Michelle Monier, Nadine Juillard, Maryse Leisieur, MarieBernadette Thomas. Many of these players would later be recognized as playing in the first international match retrospectively recognized by FIFA as the first women's international. On 17 April 1971, Stade de Rheims, playing as France defeated the Netherlands, 4-0, at Stade Auguste Damette in a qualifying round for the unofficial Women's World Cup in Mexico. ${ }^{15}$

In the final match, newspaper reports commended the speed of Manchester Corinthians and their combination play, which was able to outdo the 'catenaccio' tight defence of Juventus for a 1-0 victory. Although I have been unable to name the Juventus lineup, either through programme notes or press coverage, the Corinthians players were: Christine Miller, Pauline Quayle, Janice Lyons, Margaret Wilde, Margaret Taylor, Margaret Temple, Margaret Whitworth, Patricia Quayle, plus Eileen Gay, Sheila Isherwood, Sue Kelly, and Linda Hallam, who all received a winner's reception at Hotel de la Ville 6 July, reported in l'Union newspaper. Margaret 'Whitty' Whitworth made a big impression in the final, winning player of the game. ${ }^{16}$ Since at one point there were seven players with Margaret as a first name in the team, nicknames were to prove vital.

This seems to have been the last big Corinthians international tournament win, and perhaps the Pierre Geoffroy connection explains why. Stade de Rheims went to the unofficial women's world cup in Mexico in 1971 representing France. In 1971 The British Independents Football Club, led by Harry Batt represented England, although the WFA insisted that they could not, and did not, carry that title. As has been outlined in previous academic work Batt and the players were then 'banned' from WFA activities on their return, although he did later take an England team to Italy in 1972 before being 'banned' for life by a WFA committee and giving up on women's football altogether. ${ }^{17}$

Batt had previously been a member of the WFA committee and attitudes clearly differed over how best to develop women's football. Having seen how 'unofficial' internationals were handled by the WFA, maybe Gladys Aiken decided official channels provided better options. Maybe too, she agreed with WFA policy. By not explicitly calling themselves England, but representing England in the 1970 tournament as a club side, Corinthians were able to tread a fine line which evaded WFA sanction. The Women's Football Association invitational tournament for the Teddy Gray Memorial Challenge Trophy featured both Corinthians and Nomads, with the former victorious in 1968 and 1969 losing to Southampton in 1970. ${ }^{18}$ As the 1970s progressed, trainer Ray Vaughan continued to put his team through their paces, at Woodley Sports Club on Sundays and Brinnington Leisure Centre on Tuesdays. Affiliated to the WFA, Corinthians and Nomads played in the Three Counties League, becoming winners of the Women's Football Association Mitre Cup. With less frequent fixtures, the club splintered into different teams such as Veronica Bailey's Benfica Beechams and and Red Star Manchester, which would become Manchester City women's team sometime in the mid 1980s.

\section{Oral histories of Corinthians on Tour}

\section{Carol Aiken}


I was always sporty, and played boys games and loved football. I also played badminton, hockey, netball, and did trampolining. I am not sure how I heard about the Corinthians, but my parents went for an interview with Percy Ashley off Fog Lane, in Didsbury and I remember that they were looking for a goalie, although I was really an outfield player, and I was accepted. I had to be fitted for football boots. We were not a particularly well off family and my sister was not sporty so my Mum and Dad said, 'You had better be serious about this' as they stretched their finances to buy my boots. They were not regular season ticket holders or football fans either, although my Dad took me to Maine Road to see some top class football to encourage me and to see what to aspire to. I was serious! I would practice for hours, angles of shots and passes and returns with a tennis ball against a wall. I started playing for Corinthians aged fourteen when Doris Ashley was still playing. We always played for charity and it was usually a charity match against Nomads.

Funnily enough, I don't remember the games as such. Maybe while I was playing I was one of those people who were 'glad to be there.' I can't remember the scores and such. I became an outfield player at Corinthians and played centre half, although I wasn't as skillful as in goal.

I went on the tours to Morocco and Tunisia on a plane for the first time and was allowed by my school to go, during term time. It felt very prestigious, and quite important playing exhibition matches. I was fifteen at the time and had been on one foreign holiday to Switzerland. I was amongst the first at school to get a passport and I took the photos from the football tour to school to show my friends. The names of the places seemed exotic, Casablanca which people had heard about because of the film, Rabat, Hammamet and in all about five cities where we played in proper stadia, with large crowds and we were chaperoned to the grounds where we played. I remember the dry heat and the drums, and the Red Cross crescent. Then we prepared for the Rheims tour. My Mum led the tour and she managed the team. My brother in law coached at Corinthians after Mum gave up as manager.

I trained as a PE/ French teacher at Coventry College of Education between 1969 and 1972 so training was difficult because I was also trying to do athletics, hockey, netball, rounders and volleyball. I've always been sporty and always loved travel, doing as much as I can now I am retired.

In 1973/74 season I moved to Fodens, aged twenty two as I felt that it would help with my ability and played in an WFA Cup Final then ended playing in 1975/6 season. This was the pinnacle of my career. I travelled to Sandbach by train. I played alongside England internationals like Sheila Parker and Sylvia Gore at Fodens. I had a partnership at the back with Sheila Parker who was a model professional and, by then, I could tell it was not going to be a career. I knew I wasn't as good as Jeannie Allott who went, I think, to Holland and then to Juventus. In the WFA final itself against Southampton, we went by coach from Sandbach, with no particular send off from Fodens and we were not intimidated by them. Fodens scored first! With the great England international Sue Buckett in goal for Southampton, this gave us great confidence. I do remember getting a bollocking from Hazel Bancroft for giving away a free kick, but can't remember why. It may have 
been extra time? Alison Leatherbarrow, the England defender, nicknamed 'Tiger' also played. We were featured on TV when we won but again I can't remember the broadcaster. Folks would say, 'You won the FA Cup Final and I saw you on TV.'

\section{Annie Grimes}

Winning in Germany in 1957 was a big achievement and gave us a staste fir the major stadiums. When we played in Portugal, we filled the Estádio José Alvalade in Lisbon, with 50,000 people and also played at Benfica stadium. Playing on Fog Lane Park did not necessarily prepare you for this but Percy Ashley did. He would coach individuals and took the science of the game very seriously. There would always be a blackboard and he would expect individuals to do a specific job on each match. Between him and Eddie, the two of them taught us tactics, like what they call today wingback, those overlapping runs. Well we were doing that in the 1950s! Our keeper could not send a dead ball 60 yards when she started but they taught her, and that was a huge advantage. In spite of being deaf in one ear, Doris was very good. Her mother was the welfare officer and Doris would be very strict. We sometimes called her the De Stefano of our team. Again, in the Netherlands we played in Haarlem and Utrecht, in front of very large crowds, and the International Red Cross appreciated our efforts for their charity.

When we left New York for Venezuela and the engine caught fire, Percy would not allow us to fly that airline again. He insisted that we go with Lufthansa.

To get to the Humboldt Hotel, you could only use the cable car to get up the mountain and there was some kind of protest or revolt in the town lasting a while, so we couldn't go down for a couple of days. From the luxury of our rooms though, we could see poverty and rats as big as cats. It was very humbling and travelling made a big impression on me. We played against Costa Rica and shared rooms 3 to a bedroom.

The breakaway group was Babs Large, her mother, Mrs Large and Veronica Bailey but they didn't have the organization that Percy had. I remember him being absolutely serious and insisting we were taken seriously. One time at an airport, I think it was in Brussels, we came across Walter Winterbottom and Sir Stanley Rous who asked if we were a gymnastics team and Percy said no we were a women's football team and when they laughed he had a right go at them. He was such a nice man. Very kind. But absolutely serious about what he did.

\section{Marlene Goddard/ Cook}

I played for Corinthians for a relatively short time between 1958 and 1963, but I played hockey for South Manchester for fourteen years until I was about thirty-six or thirty-seven. We played hockey in the south Manchester League, which was so large that it was teams entirely comprised from Manchester city, itself. I played in goal for my hockey team, and made an appearance in the North of England regional team. For Corinthians, I started out as a forward, but when the split came after Portugal and some of the 
team had an argument with Percy, and then formed Benfica Ladies FC, I was moved to left full back. I don't know what the argument was about but Babs Large, who was a brilliant left-winger, was part of Benfica and I think her mum and sisters helped organise the team but they didn't play for long after. They liked the name while we were on tour and after the Portugese tour formed their own team. It wasn't that there were too many in the squad for Corinthians and Nomads, it was something else but I am not sure what the argument was about.

In my time with Corinthians I went on tour to Holland, Portugal, Madeira, and three months in South America. They wanted us to stay longer, but we had been away from home so long and some of us were quite young, so we wanted to go home. Margaret, 'Titch' Wilde was only twelve after all. So Percy spoke to everyone who was of age, and those who were not, he spoke to their parents. South America was my last big tour because I got married in 1961 and didn't go on tour then. My maiden name was Goddard and my married name was Cook, so I didn't really have a nickname before marriage as there was only one Marlene and after we had two Cooks so I became 'Cookie'.

What I remember most about the tours were the crowds, twenty to thirty thousand people regularly watching us play in large stadia and staying in top class hotels, where the wealthy people would stay, with different foods and entertainment and different cultures. There were various media responsibilities, such as in Surinam we had to ride around on a big fire engine through the streets to promote the game, with advertising all over it. After marriage and giving up with the Corinthians I have always continued my love of travel. My Aunty lived in America and I took the children over to see her several times. I have four sisters, who live in Australia so we regularly visited when my husband was alive and, after he died I went on my own. Now, I love all sport on television, if there is sport on, Marlene will be watching! I support both City and United, both Manchester teams, but I support United a bit more.

\section{Margaret Shepherd}

I joined Corinthians, aged nineteen, in 1966 or 1967, I had not really heard of women's football in my little Lancashire town, although I used to play football and cricket with the boys. Not long after I started work, I got picked for the civil service netball team in my area. Going along to practice, I kicked the ball as it ran along the ground to me as I would kick any ball. Another girl the other end kicked it back! She said, 'Do you play football?' I said 'Girls don't play football but I play with lads on the local field.' She said, 'You've not heard of women's football then? I play in a women football team, do you want to come and train?' It was Sheila 'Isshy' Isherwood and she was a really good player. It was just by chance. She lived in next town and invited me to go with her on the bus to train on Sunday at Fog Lane park. I came from a mining town so even going to Manchester on the bus was an experience. We were both in the civil service on $£ 5$ a week. The changing rooms were dingy and if you wanted a wash you had to break the ice on the duck pond if you didn't want to go home on the bus with muddy knees. 
But it was freedom and then we were never in. We would work in the beer keller on a Friday and Saturday night, pack a bag of food for the bus and off out playing football.

I was part of the team who won in Rheims France, and Corinthinans won against the Italians in the final. It was very professionally organized and I remember we were treated very nicely. There were plans to go to South Africa following the tour that Chelsea had just completed but trouble in Mozambique meant that we had to cancel and we were bitterly disappointed.

We had to be resilient! We went down to Deal every year to play in WFA cup, returning after matches on Sunday night by coach, we used to return in the early hours and have to go to work first thing. Then, if you got through to the later rounds in Deal you had to go back and do the whole thing again the next weekend. However, increasingly from we started to play Fodens, Doncaster Rovers Belles and Southampton, those kinds of teams.

I gave up playing for Corinthians in my late 20s when my daughter was born. In her early teens I set up a girls team because there were a lot of youngsters just roaming the streets. So I got a group of girls to play football and they were changed kids! So I did my bit for women's football in the modern era starting about 1992-1993, for about three years until with commitments like looking after my parents, I had to give up.

\section{Margaret 'Whitty' Whitworth}

I joined Corinthians when I was eleven and was fourteen when I joined the main teams, which was inspiring because there were so many good players. My first flight was the tournament to The Netherlands, and I found it really well organized, and thrilling to be doing something I couldn't have afforded back home like staying in hotels, going on planes and so on. The hotels were always top quality.

For me, the stand out tour was to South America, which should initially have been six weeks, but went so well that the management wanted to stay on, when we previously had planned to return and play in Holland. This caused a bit of bad feeling with the Dutch organisers but as players we were delighted. It wasn't all glamorous; the flights in South America included a late night trip on a cargo plane. Before I could go my parents had to get the permission of the school education authority, who agreed to the six weeks because it might be educational. When the tour was prolonged to three months my parents had to go back and ask for extension. All my Dad kept saying was, 'Bring me lizards back.' He was a curator at Manchester Museum and always on the lookout for new specimens.

But mostly, it was very glamorous. I felt like a star staying in top class hotels, where wealthy people stayed, lots of media attention, people gave us gifts at airports and at hotels and telegrams of good luck. Even a proposal of marriage! I was only fourteen. We went to a lot of receptions, with politicians and the well to do. It was non-stop really.

Being part of the younger group, we got into some scrapes the manager didn't know about, and so we also had to keep quiet when Doris was around. For example, we formed a plan to go midnight swimming at the hotel 
Humboldt in Caracas, which had two lifts, one for the guests and one for the maids. We went down in the maids' lift and were swimming around when one of the girls couldn't resist diving in, causing a big splash. Someone came to investigate and we all had to hide around the pool. We thought we would be locked in until morning. But fortunately we climbed the steps back to bed.

Percy was very proper, 'My Girls Are Ladies' he used to say. So another time in Paramarabo the hotel was right on the beach, right by palm trees and the sea, and although we were told not to go out unless supervised, a few of us went onto the beach and one girl was sitting with a lad, when a woman from the hotel saw us. She began shouting, 'he's got a knife, he's got a knife!' Of course he had nothing of the kind, but we were made to apologise to the older players and the management because they were afraid for our safety. Percy was very kind but very correct, in that respect.

We played to full stadiums of people with 50-60,000 spectators. Having previously played at sports grounds in England, when we went abroad it was completely different and felt very professional. Sometimes I was a bit intimidated, at the age of fourteen I played teams in South America such as Odica and Caracas, we kicked off at $10 \mathrm{pm}$ because of the heat and after the President had arrived by helicopter and after a big parade. It could be a little bit frightening as I hadn't experienced anything like this. We played exhibition matches, of course too, and even on our nights off, when we went to the cinema, on the newsreel it was us!

Percy used an agent Virriato Kavachio, who I think was quite wealthy himself, and put money up front to organize the tour, then he would donate the money to the Red Cross, minus our expenses. In Venezuela alone we handed over a cheque at a reception for $£ 12,000$. So there would be sixteen players and maybe four managers/ agents, so it was a huge undertaking. While we were in one place, Kavachio would go on ahead and organise the next venue. This meant that when Pauline Fairweather got appendicitis in Aruba, one of the other girls had to stay with her, and an agent. They had a nice holiday but Pauline had to go home to recuperate and so they had to go with her and missed the rest of the tour.

Compared with this, the tour to Italy in 1961 was a bit of a flop crowd wise. Although we played in Turin, Milan and Bologna. The Ireland tour of 1962 was just a couple of matches in Ballymena and followed by a tour of the Isle of Man. I couldn't go to Morocco as I couldn't get the time off work. We were an amateur side who worked. I now think, 'what if people had taken women's football seriously because we had some really very good players who could have been in any England side?' I was so lucky to go. When I got back my outlook on life totally changed. When you've been to a place and then see it in a geography lesson, you know what that place was like and who was rich and who was poor in that country and how they lived, Since then I have travelled widely and love travel, especially to Canada, and America.

One time against a Coventry side, as Dunlop sports ground I think, I had already scored seven and because we were so far ahead, we swapped the defence with the attack to liven things up, and I scored my best goal ever! A diving header the only time I scored with my head. I was a right-winger. 
Margaret Wilde was an unbelievably good player, powerful and brilliant with her feet.

I played until I was 27 when a knee injury ended my career. There wasn't the surgery available then that there is for ACL injury now. I never played for another team than Corinthians but was once loaned to Benfica, who were a team created after some of the players had a row with Percy and formed a breakway. I was terrified and couldn't wait to go back, from manager Madley? My last tournament was 1970 in France where we played the French, managed by Pierre and his wife Christine, it was very well organized and we beat Juventus in the final by a single goal. They were very Italian in their play. Very defensive. Four of us went back in 1971, camping and met up with some of the French players. My memory of the winning reception in 1970 at the Lord Mayor's offices, was us all standing round in two piece suits, with little handbags and all the other players from other countries looking very professional in tracksuits. Meeting the Lord Mayor lined up in little two-piece jacket and skirts! But that was Percy, very correct.

\section{The Fusion and Confusion of 'unofficial' and 'official' women's football 1969- 1972}

As the career of Sylvia Gore, and Jean Wilson highlights, Manchester Corinthians, and especially their overseas tours, were absolutely vital in developing a cadre of young women players during the period before which women's football was considered worthy of recognition by FIFA and the FA in England. In this Percy Ashley, and Derek Ingham, like Harry Batt and his Chiltern Valley team, have to be considered visionaries before their time. ${ }^{19}$ Compared with the treatment of Pierre Geoffroy, where Stade de Rheims, a club side, represented France, without sanction, we can see that both Manchester Corinthians and Chiltern Valley represented England abroad before an official WFA England team was convened. Flo Bilton in 1963 formed Reckitts and a ten team Hull League, before becoming a WFA stalwart, so the contribution of men and women administrators needs analysis. But Corinthians doing this in 1957, it seems was interpreted differently than Harry Batt's side in 1971 by the WFA, even though Corinthians had played in the Stade de Rheims European tournament in 1970. The link with Stade de Rheims, suggests that Corinthians were linked with the same international network as Batt, who in 1970 took an England team to the unofficial Women's World Cup in Italy.

With Gladys Aiken assimilated to the WFA, and Harry and June Batt awarded a lifetime expulsion from the WFA after the Mexico trip in 1971, the politics of the situation was clearly complex and changeable. A reported profit of $£ 250,000$ in Mexico was considered by the WFA to have jeopardized the players' status as amateurs. ${ }^{20}$ This did not prevent Batt taking an English team to a tournament in Italy in 1972, many of whom were Chiltern Valley players who had been 'banned' by the WFA before returning to play in other teams. His involvement with such activities and his links with a planned Women's World Cup in England in 1972/3 are likely to have prejudiced an already wary WFA against the enterprise. Others have told me that they considered the situation so ridiculous that they gave up football altogether shortly after. This was not the first iteration of a women's England team of course, and Alfred Frankland had done this before in the 1920s, as had teams in 1881. 
In Corinthians, not only did Percy Ashley create a team, which then grew to a club of three sides, he also used overseas tours to develop a level of technical playing ability that the domestic game at the time could not sustain. If Manchester Corinthians were defeating opponents like Coventry 36-0, with individual players like Whitty scoring seven goals and using such matches as experiments between their defensive and attacking players, then going abroad could provide more rigorous tests of opposition. Even the exhibition matches, where the Corinthians and Nomads players teams were evenly matched across the sides, in order to provide high scoring and open matches, must inevitably have raised the quality of play, as did regular practice. It is intriguing to know why Benfica Ladies FC broke away from Percy Ashley's organization, but it does seem to have been a short-lived team thereafter.

Gore joined Corinthians as a twelve year old, which, as we have seen from player testimony was not that unusual, and joined the international tours before signing for Fodens in 1967, a great opponent of Corinthians, as were with the more recently formed Southampton side for which Sue Lopez played. Gore was twentyeight years of age on her England debut, while Wilson was twenty-three. Wilson's England career was more shortlived and she remained a Corinthians player. This meant that when the WFA did form the first official England side to play Scotland in 1972, Gore had over fifteen years of expertise on which to draw to score the first goal in a 3-2 victory. Wilson was less experienced and was named as a substitute in 1972, waiting until 1973 for her England debut. 'Whitty' was one of the forty five women players invited for the trials for the official WFA England side, but a quota of eight places was given for the league in which she played and she didn't make the cut to twenty five players who were invited to Loughborough University for a final squad selection. ${ }^{21}$ Perhaps her best years were to be for Corinthians rather than England, which came too late.

While Arthur Hobbs (particularly in relation to the Deal international tournament which he created from 1968 onwards) has often been credited as the godfather of women's football by the WFA, this was a complex organization, with many factions and schisms. Hobbs may have held sway at the WFA, but the treatment of Pat Dunn, who specifically referenced a phone call from him requesting her resignation in 1969, and the later treatment of Batt and Chiltern Valley, plus the issue of the missed opportunity to host a Women's World Cup meant that the fusion, and confusion, about what was considered official and unofficial remains to be further unpicked with a detailed study of the WFA itself. Dunn, the first woman to qualify as an FA referee in 1967, was finally allowed by the FA to officiate an auspicious fixture between Rolworth Rangers v Free Wheelers in the Dorset League on 5 September 1976. She continued to referee for a decade before giving up on football altogether. How many more women have been lost the sport due to this kind of treatment is likely to remain a large and ultimately unanswerable question.

As well as the 44 English clubs, one Welsh and five Scottish clubs joined the WFA in 1970 each paying $£ 1$ 10s, for a total of $£ 76,10$ shillings so gradually, Scottish and Welsh associations formed from there. ${ }^{22}$ This article has begun to address a much larger question, at a pivotal time for women's football, and which arguably still shapes the phenomenon today. By 1982, the FA had granted the WFA $£ 3,000$ per annum, possibly rising to $£ 4,000$ by 1985 , for its expenses. ${ }^{23}$ Nevertheless the WFA meeting that recorded this historic breakthrough also noted that it was not uncommon to spend over an hour discussing the thorny question of expenses and 
subscriptions, with fines issued to individual teams and to leagues who did not comply. An invitation to play in Norway in 1982 was declined due to finance and women who wanted to avail themselves of a coaching experience in New Zealand, including England captain Debbie Bampton, were advised to self-fund. By 1983, the WFA had become a limited liability company, but ultimately this did not end its penury, and financial problems and irregularities were at least one of the reasons that the FA took control of women's football in 1993.24

\section{Conclusion: Born Kicking}

In 1992 ten year old Tracey Wright appeared in Born Kicking, a BBC One Screen One production by Barry Hines, featuring protagonist Roxy Reddy, the first woman to play professional football for fictitious league side EPR. This was a fiction, in 1992, as forms of professionalism had been pioneered before the programme, but the pitch of the script as a 'futuristic drama' shows how important amateurism was to the WFA during its twenty year reign over women's football in England between 1972 and 1992. Importantly, women's football was perceived as ideally amateur in nature in Britain. No home nations qualified for the first Women's World Cup in 1991, and it would take for the second Women's World Cup in Sweden for a more organised approach. Amateurism had an important part to play in the acceptance of women's football from 1949 to 1969, and this changed only gradually up to 1992. This article has shown how Percy Ashley bought civic psychic goodwill for his players during the time of the FA ban by consistently telling a story of female amateurism, at a time when football's retain and transfer systems, and maximum wage caps were being challenged. From the 1950s stars like Billy Wright and, later in the 1960s, George Best, were pioneering new kinds of male professionalism and links with the entertainment and media industries, for ever higher personal gain. of course, many women's teams had used charitable fund raising to host women's matches in major stadia during, and more successfully still, shortly after World War One, before the 1921 ban. However, the Corinthians case study suggests a need to examine how similar tactics were used after 1945, in peacetime. Amplifying this example with other local studies, can help to contextualize the gradual acceptance of women's football as officially sanctioned by governing bodies, and the 44 clubs of the inaugural WFA season seem like a good place to start.

The Corinthians and Nomads players may have life experiences that they otherwise would not have had without their enthusiasm for football, but by raising vast sums of money for a range of charities, the wider societal disapproval of women playing the sport could be offset by presenting a kind of robust, plucky sporting altruism, typical of Manchester's reputation for busy worker bees. Ashley was not just an astute football tactician, but wise in public relations, and in networking.

Percy Ashley had already pioneered complex and ambitious overseas tours twelve years before the WFA were in a position to have domestic trials for an England team. He understood that businessmen, and philanthropists could make women's football spectacular, if ambitiously staged and sold to a paying public as exciting entertainment. Harry Batt agreed. The WFA and the FA did not, and have continued to perceive women's football as an economic drain on resources rather than as a financial asset today. There is still much to know. Elsey and Nadal recently indicated that the South American tour was intended to include Brazil and that businessman José da Game supported the intention, only to have it blocked by the government who had, at that time banned women's football by law. ${ }^{25}$ It would also 
seem that the tour to Tunisia was not as successful as some of the other overseas trips, and the players were not encouraged to speak about it, upon their return other than as a nice holiday. So there is a lot more to do to understand both the full extent of plans for the tours and exactly how each was organized, as well as the other Corinthians internationals.

The article has shown the processes by which the Corinthian and Nomads players became mediated as ambassadors for respected international charities. In this, there is perhaps something new that had not been tried before in promoting women's football, even by big name clubs such as Dick, Kerr Ladies. This ambassadorial role, now very fashionable amongst movie stars and celebrities today, also gave Corinthians a gloss of international approval, which helped their image domestically. Most of the aid charities I have seen in the source material so far were large and complex aid agencies, like Oxfam or the Red Cross, or health charities for serious and complicated conditions. There was an absolutely serious approach to women's play and an ambitiously professional level of organization, combined with a committed social conscience.

Compared with this, the FA gave the WFA no funding initially, which meant that the only funding was from the Central Council of Physical Recreation (CCPR), which in turn only funded amateur sport. Although the ban on women playing was lifted for instance, it took a campaign by the WFA to be able to use FA pitches, so there was a very protracted aspect to accepting women's football. As such success was limited. The original 44 clubs had risen to 269 in early 1972, to only grow to 373, as the WFA handed over to the FA in late 1992. England's first women internationals had to be amateur, and were prohibited from being professional in either their outlook, or preparation. For this reason, many had to choose between playing for their country or playing abroad, as Sue Lopez has outlined. ${ }^{26}$ David Marlowe, Chair of the WFA, reiterated a commitment to amateurism as the most desireable future for the women's game on 1975, and again on more than one occasion. ${ }^{27}$

The WFA was so poor that Flo Bilton, a stalwart of the women's game who founded Reckitt's in Hull and helped to found the WFA, had to make the England caps by hand. Debbie Day has kindly shown the author a photograph of the hand-stitched caps which were awarded to each player on her first appearance. Sheila Parker was the first England captain, between 1972 and 1976, winning 33 caps all told. Carol Thomas, the first woman to 50 caps and a longtime England captain 1976-1985 (except Wales 17/08/85), has no special memento edition cap for her $50^{\text {th }}$ appearance, still to this day. ${ }^{28}$ Debbie Bampton, MBE, shared the England captaincy and was a room mate of Gill Coultard between 1985 and 1993, winning 95 caps in all with the changeover due to injury, illness and controversy. Coultard became the first woman, fifth England player (male or female) and only amateur to reach 100 caps in October 1997. Before a 1999 World Cup qualifier against Holland at Upton Park, she was presented with a silver cap, and silver lion momento by Sir Geoff Hurst. Bearing in mind that the WFA was so cash strapped that they played just eleven internationals in 1990, when Gill first took over as captain, eight in 1991, and 6 in 1992 before the FA took over in 1993, that her career represents an incredible resilience. As an amateur with a full time job and limited access to top flight football, this should be recognized as a momentous achievement. Fifteen years later, the FA presented her with a gold cap, as it had done men who reached the century milestone. ${ }^{29}$ Again, while Rachel Yankey, who debuted in 1997 and went on to surpass Coultard's achievement with 129 caps during an era of 
Women's World Cup, and Olympic tournament competition, has been recognized by an OBE, Parker, Thomas and Coultard remain overlooked, of the four England captains of the WFA era. As so many of the games before 1993 were not recognized as official internationals, they have the status of international friendlies, and, though recognised by the FA with a virtual cap as representative games, many women players do not have more than one or two caps for their country as a result. This is a symbolic, but not insignificant, reflection of the FA attitude to the historical aspects of women's football.

The more recent take over of women's football by the FA in 1993 has seen a very steady rise in numbers, and football remains a sport practiced by girls mainly outside of school, rather than in PE lessons. Given this highly gendered experience of physical education in 2019, compared with other aspects of the curriculum which are more integrated, we may well look back on feminist fathers like Percy Ashley as well ahead of their time. Not that he would probably have used those terms himself. But in practice, what he did for his daughter, his local community, many charities and for women's sports undoubtedly merits more recognition than he has so far received. Similarly, the players who gave up so much of their time for charity, and challenged convention to play a sport that they loved, even when the prevailing conditions were against them and it would have been easier to go off and do something else instead, deserve recognition and respect. We get a sense of how fragile the good fortune of a young woman to be geographically close to clubs like Corinthians could be from an aspiring Anne Day, who began to play football aged 8 and wrote to Manchester Corinthians aged twelve in 1970 to ask to play, only to be told by her parents that she was too young to travel with the team. ${ }^{30}$ Undaunted, she formed her own team, and went on to have a career in coaching. But it could have been so easily different. It is satisfying to know at least, from the oral histories, that all involved had a lot of fun and some fame, if short lived. It would be useful to extend the player evidence with views of those charities involved to know why and how women's football was used in this way. Much remains, then, still to be done.

The author is particularly grateful to Tracy Cook, daughter of Marlene, and the women of Manchester Corinthians for their help with this article. Programme notes were kindly provided by John Carrier a historian of Welsh soccer, and particularly the women's game. Thanks also to Joanna Compton of jjheritge.com and Belinda Scarlett and Tim Desmond of National Football Museum for hosting the women's football reunion 30 September and 1 October 2018, where many of the Corinthians players gave us their stories.

\footnotetext{
${ }^{1}$ Jean Williams A Game For Rough Girls (Routledge, 2003) p. 11.

2 Margaret Whitworth and Margaret Shepherd Oral History Interviews The National Football Museum

3 Jean Williams A Contemporary History of Women's Sport, Part One: Sporting Women (Routledge, 2014) p. 129.

${ }^{4}$ Jean Williams A Beautiful Game: International Perspectives on Women's Football (Berg, 2007) p. 138-9.

${ }^{5}$ Alex Jackson (ed.) The Greater Game: A History of Football in World War One (Shire, 2014) p. 35.
} 
${ }^{6}$ Manchester Corinthians Manchester Corinthians Versus Lancashire Programme Craven Park 3 June 1951 p. 3

${ }^{7}$ Carrie Dunn 'Sylvia Gore: Obituatry' The Guardian

https://www.theguardian.com/football/2016/sep/15/sylvia-gore-obituary accessed 6 August.

${ }^{8}$ Esther Rose 'Chuckles or Cheers?' Daily Express 22 April 1960 p. 12.

${ }^{9}$ Kath Davies 'Memories of A Corinthian Lady' Unlocking The Hidden Histories of

Women's Football Blogs National Football Museum

https://unlockingthehiddenhistory.wordpress.com/2017/10/10/kath-davies-

memories-of-a-corinthian-lady/accessed 4 August 2019.

10 Manchester Corinthians versus All Star XI Programme 19 May 1967 Brighouse

Waterloo Roads Playing Fields

https://unlockingthehiddenhistory.wordpress.com/2017/10/10/kath-davies-

memories-of-a-corinthian-lady/ accessed 4 August 2019.

11 Manchester Corinthians versus National All Stars Ladies XI in aid of the Cambrian

Colliery Disaster Fund 28 ${ }^{\text {th }}$ August 1965 Belle Vue Stadium Manchester p. 3 John

Carrier Collection sent by email to author.

12 Manchester Corinthians versus All Star XI Programme 19 May 1967 Brighouse

Waterloo Roads Playing Fields

https://unlockingthehiddenhistory.wordpress.com/2017/10/10/kath-davies-

memories-of-a-corinthian-lady/ accessed 4 August 2019.

13 Pierre Geoffroy Stade de Rheims FC (French spelling) to Gladys Aiken 20 April 1970 Gladys Aiken Scrapbook 2 National Football Museum, Preston.

14 Pierre Geoffroy Stade de Rheims FC (French spelling) to Gladys Aiken 11 May

1970 Gladys Aiken Scrapbook 2 National Football Museum, Preston.

15Jeré Longman 'In Women's World Cup Origin Story, Fact and Fiction Blur' The

New York Times https://www.nytimes.com/2019/06/25/sports/womens-world-

cup-france.html accessed 5 August

${ }^{16}$ Anon Sir Alf Please Note The Daily Express 6 July undated Gladys Aiken Scrapbook

2 National Football Museum, Preston.

17 Jean Williams, Joanna Compton and Belinda Scarlett 'Sporting reunions, contemporary collections and collective biographies: a case study Harry Batt's '71

England Team' in Kay Biscomb, Kath Leflay, Alsion Forbes, Tina Smith and Jean

Williams (eds.) Upfront and Onside Special Edition: Sport in History 39: 2 June 2019, pp. 229-250.

18 The Women's Football Associaiton 1970 invitational tournament for the Teddy Gray Memorial Challenge Trophy 28 June 1970 Deal Kent Programme' WFA

Archive MS 89306/4/1 British Library.

19 Jean Williams et al. 'Sporting reunions' p. 229.

20 David Marlowe 'Minutes of a Meeting at the Midland Hotel Birmingham between the WFA and Mr and Mrs Batt 11 November 1972' WFA Archive MS 89306/6/1 British Library.

${ }^{21}$ David Marlowe notes 'England Squad selection 2 July 1973’ WFA Archive MS 89306/2/26 British Library.

22 Pat Gregory ‘Our Tenth Anniversary’ WFA News January 1980 p. 3 WFA Archive MS 89306/5/5 British Library.

23 The WFA WFA Council Information Sheet Number 1124 March 1982 WFA Archive MS89306/3/6 British Library. 
24 The WFA WFA Council Information Sheet Number 1511 April 1983 WFA Archive MS89306/3/6 British Library.

${ }^{25}$ Brenda Elsey and Joshua Nadel Futbolera: A History of Women and Sports in Latin America (Austen: University of Texas Press, 2019) p. 127.

${ }^{26}$ Sue Lopez 'Sisterhood and After Feminists' The British Library

https://www.bl.uk/people/sue-lopez accessed 6 August 2019.

27 David Marlowe ‘Women's Football News 29/01/75 WFA Archive MS 89306/2/26 British Library.

${ }^{28}$ Carol Thomas: England Captain 56 caps Oral History interview with the author 1 July 2019.

${ }^{29}$ Gill Coultard England Captain 119 caps Oral History interview with the author 1 July 2019.

30 Anon. 'Ann, 12, forms football team' Lancashire Evening Telegraph 31 March 1970 Anne Ellwood personal collection. 